\title{
Surveillance of air pollution: Some reflections on its actual state and future needs
}

\begin{abstract}
W. Baehler
Some considerations are made about the reduction of the swiss air pollution networks. The tasks and the needs in the field of air pollution monitoring are sketched with a parallel between Europe and Switzerland. Trends in the gestion of human and technical means are outlined. The increase in european monitoring sites is questionned based on the ratio cost/efficiency.
\end{abstract}

\footnotetext{
T
} he distinction between polluted air and clean air is the issue of noticeable damages produced by certain substances existing in the air. With this concept in mind, we try to separate "good" from "bad" atmospheric compounds. This creates problems when, for a given pollutant, we attempt to determine those which are produced by man from those which are produced by nature.

Until the 19th century, the air pollution problem was mainly caused by local problems. With mass production introduced by the industrial revolution, the first serious accidents appeared, provoking premature deaths.

In the early 1950's, the first national legislations on Air pollution appeared. In the frame-work of the European Union, a supranational legislation whose task is to determine the common objectives and limits, is progressively replacing the national legislations.

\section{The Swiss Situation}

At the initiative of some communal and district (cantonal) administrations the first measures of air quality began at the end of the 1950's. With the enforcement of the "Federal Law of Environmental Protection" (LPE), 7th of October 1983, and then the Federal Ordinance on Air Protection (OPair), 16th of December 1985, the deployed activities by some communities, districts, and the Confederation, received a legal base.

By the end of the 1980's, the number of measuring sites and of measured pollutants has highly augmented. Due to financial constraints, we are observing a reorganization $[1,2]$ of networks (Tab. I) which accounts for the noticeable decrease of sulfur dioxide concentrations (Fig. 1) and the tendency of the nitrogen dioxide decrease (Fig. 2) that is observed, in general, in Switzerland.

\section{Duties of an air protection service}

Administrational activities are guided by legal regulations. In the realm of air protection and without going into details, we can distinghish Planning activities and Air quality management activities.

Regarding the Planning matter, the Federal Ordinance relating to the study of the Impact on the Environment (OEIE), 19 October 1988, is one of the legal instruments which enables the evaluation of consequences of a construction project and notably the verification of its compatibility with air quality. For this evaluation, it is often necessary to appeal to the prognosis of emissions and immissions.

In the matter of Management Activities, OPair predicts:

- The control of stationary source emissions and their purification if the emission limits are exceeded.

- Immission surveillance.

- A plan of air purification in regions where immission limits are exceeded.

- Information to the public.

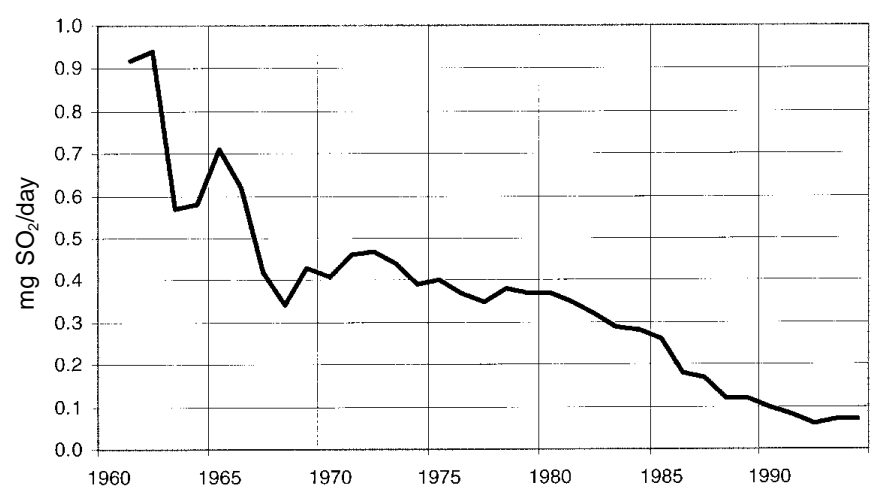

Figure 1. Evolution of Annual Flux of Sulfur Dioxide $\left(\mathrm{SO}_{2}\right)$ in Lausanne downtown (in $\mathrm{mg} \mathrm{SO}_{2} /$ day). 


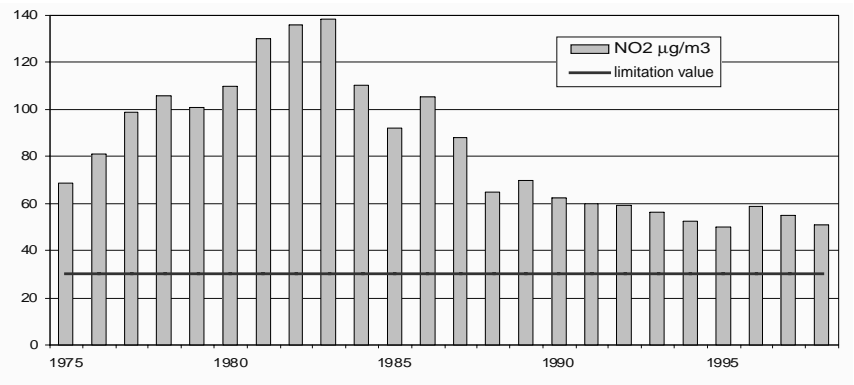

Figure 2. Evolution of the Annual Average of Nitrogen Dioxide $\left(\mathrm{NO}_{2}\right)$ in a very circulated street in Lausanne (in $\mu \mathrm{g} / \mathrm{m}^{3}$ ).

- Planning and Management are the main points of interest presented to the legislation before continuing any building project which may contaminate the air.

\section{Needs in the Area of Immission Surveillance}

The immission evaluation requires measurement studies after long and sometimes expansive as well as particular skills.

The Swiss and European administrations are now monitoring the air quality, due to its effect on man and his environment. This area of surveillance rests almost exclusively with the administration, specialists in Polytechnic Institutes, and a few engineering organizations. The routine analyses of immissions are generally performed by the administrations, whereas more complex analyses are performed by experts.

However, the problems posed in the study of pollutants, which are the object of limited immission values, are not all resolved. Developments in scientific knowledge and in transposition (Tab. II) are still necessary.

\section{Perspectives}

\section{Relationship between administration and research}

The objectives and duties of the experts and scientists are complementary and a close collaboration, which often exists, must be reinforced.

The functions of state-employed scientists are in particular:

- To assure there is a sufficient quality of air, as defined in Switzerland by value limits of OPair and in Europe by the Council directive 96/62/CE [3] as well as by the proposal 97/0266 [4].

- To control the functioning of the stationary installations.

- To put into effect air pollution reduction strategies in necessary zones [5-7].

The functions of academic scientists are in particular:

- To contribute to the development of new analyses techniques.

- To develop new models (emission, immission, ...).

- To contribute to their knowledge in complex cases.

Because of developments in the European legislation regarding the protection of the environment, it is probable that the occurrence of new pollutants will have to be surveyed.

\section{Management resources}

Physical methods have progressively taken over the techniques used in the 1970's which consisted principally of chemical aqueous methods. Electronical and informatic knowledge have become indispensable for network users. Constantly worried about analytical quality, these users are more and more interested by the certification process.

Contrary to the practices of the previous decades, the relation between cost and effectiveness must today be better taken into account and we will have to probably resort to more expensive techniques in terms of investments, but requiring less manufacturing costs than traditional methods.

Table I. Estimation of the diminution of the Swiss number of air pollution continuous analyzers between 1992 and 1996.

\begin{tabular}{lcccccc}
\hline Diminution & $\mathrm{SO}_{2}$ & $\mathrm{NO}_{2}$ & $\mathrm{CO}$ & $\mathrm{O}_{3}$ Suspended Particulate Matter & Sediment Particulate \\
\hline Analyzers Total Numbers & -32 & -8 & -13 & -18 & -25 & -24 \\
Absolute Average Variation by Service & -1.3 & -1.1 & -0.5 & -0.7 & -1.0 & -1.0 \\
Relative Average Variation by Service & $-32 \%$ & $-23 \%$ & $-30 \%$ & $-15 \%$ & $-46 \%$ & $-44 \%$ \\
\hline
\end{tabular}


Table II. Some elements relative to the needs in the air pollution field (non exhaustive list).

\begin{tabular}{|c|c|c|}
\hline \multicolumn{3}{|c|}{ Impacts } \\
\hline Aspect & Scientific Knowledge & Regulation Transpositions \\
\hline Pollutants & $\begin{array}{l}\text { - New compounds research } \\
\text { relating to the observed effects } \\
\text { - Reaction of Compounds }\end{array}$ & $\begin{array}{l}\text { - Survey of the regulated compounds } \\
\text { in Switzerland } \\
\text { - Survey of the regulated compounds } \\
\text { in EU }\end{array}$ \\
\hline Analytic Methods & $\begin{array}{l}\text { - New methods for complex mixings } \\
\text { - Analyse Simplification } \\
\text { - Automation } \\
\text { - Improvement of the specific } \\
\text { detection limit }\end{array}$ & $\begin{array}{l}\text { - Simplicity } \\
\text { - Automation } \\
\text { - Inexpensive } \\
\text { - Reliable }\end{array}$ \\
\hline Data Treatment & - In rapport with the models & $\begin{array}{l}\text { - Simple Statistics } \\
\text { - Comparison with the limits values }\end{array}$ \\
\hline Storage & - Short Period & $\begin{array}{l}\text { - Long Period } \\
\text { - Normalized Data Base } \\
\text { - Accessibility }\end{array}$ \\
\hline Network & $\begin{array}{l}\text { - Spatial and Temporal Validity of } \\
\text { Data from Stations } \\
\text { - Networks Optimization }\end{array}$ & $\begin{array}{l}\text { - Installation and Exploitation } \\
\text { Methodology }\end{array}$ \\
\hline Modelization & $\begin{array}{l}\text { - Complex Models (based on chemistry - } \\
\text { meteorology interaction) } \\
\text { - Developing of the models for a } \\
\text { complex topography }\end{array}$ & $\begin{array}{l}\text { - Simple Models for a spatial representation } \\
\text { of the impacts } \\
\text { - Simple Predicted Models for the smog } \\
\text { episodes } \\
\text { - Evaluation Models for the proposed } \\
\text { assessment actions } \\
\text { - Descriptive Models for the spatial } \\
\text { and temporal evolution }\end{array}$ \\
\hline Information & $\begin{array}{l}\text { - Scientific Rapport } \\
\text { - Representation Tools }\end{array}$ & $\begin{array}{l}\text { - Representation Tools } \\
\text { (cadastral survey of the impacts) }\end{array}$ \\
\hline
\end{tabular}

The number of station in Switzerland, are relatively high [8] (Tab. III) compared to those internationally but should continue to diminish. In Europe, Union Legislation developments regarding the evaluation of air quality actually force air protection services to equip themselves [9] with additional, expensive devices to survey the atmosphere, even in the smallest agglomeration. However, the analyses of the air only provides results diagnosing the present state of the air and it would be wise to ask ourselves if these investments contribute in a satisfying manner to the struggle against atmospheric pollution.

Would a portion of the 350 million EURO devoted to the equipment in Europe be better invested in numerical modelization works? These models would enable us to put in a surveillance network which would optimize the objective of air purification.

In addition to the technical aspects, the organizational structures will equally evolve and we will probably see a
Table III. Comparison of the Analytic Effort between Switzerland and EU.

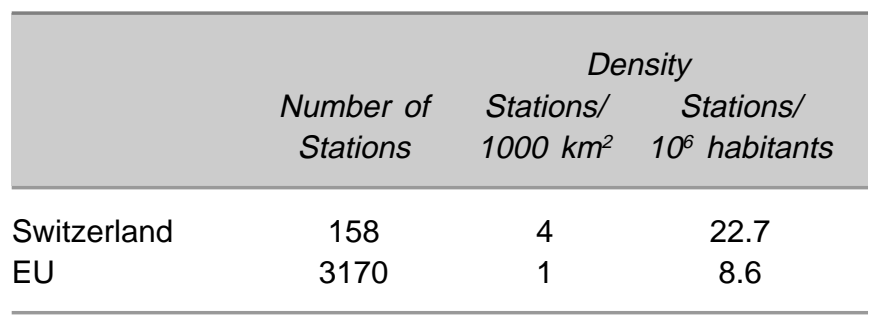

regrouping which will give way to interdistrict organizations, as well as, transregional organizations. Theses progressive changes will have a negative impact on the number of available jobs, but meanwhile this will need new type of qualified jobs. 


\section{Conclusions}

Is it necessary to stop immission measurements? The response is clearly negative. The surveillance of air quality is particularly indispensable in controlling the effectiveness of air pollution abatement undertaken and the calibration of numerical models developed in predicting tendencies and peaks of pollution. Regarding the principle of economic resources, it is suitable to study a new distribution of the limited funds available for this purpose.

After having developed air pollution abatement strategies which were essentially based on a reduction of emissions at the source, new approaches in the fight against air pollution are being developed which aim at optimizing the processes. The program "Agenda 21" [10], and its systemic approach, will possibly put processes of air purification in a more general context.

\section{References}

1. OFEFP, Valeurs d'immissions mesurées en 1992 ; Doc. Env. 1, 1993 ; p 430.

2. OFEFP, Valeurs d'immissions mesurées en 1996 ; Doc. Env. 78,1997 ; p 253.
3. Directive 96/62/CE du 27 septembre 1996 concernant l'évaluation et la gestion de la qualité de l'air ; J.O. No. L-296, 1996 ; pp 55-63.

4. Proposition de directive $\operatorname{COM}(97) 500$ final 97/0266(SYN) du 8 octobre 1997 du Conseil relative à des valeurs limites pour l'anhydride sulfureux, les oxydes d'azote, les particules et le plomb dans l'air ambiant ; proposition modifiée COM(1998) 386 final, JO. No. C-259, 1998; pp 10-14.

5. Service de lutte contre les nuisances, Plan des mesures OPair ; Canton de Vaud, Département de l'Intérieur et de la Santé publique, Juin 1995 ; p 143.

6. Service de lutte contre les nuisances. Agglomération lausannoise. Plan des mesures OPair. Évolution de la situation entre 1990 et 1995, Canton de Vaud, Département de l'Intérieur et de la Santé publique, juin 1997 ; p 60.

7. Service de l'environnement, de l'hygiène et du logement \& Service de lutte contre les nuisances. Agglomération lausannoise. Mesure des immissions au moyen de capteurs passifs. Campagnes de 1990 et 1995; février 1997 ; p 88.

8. OFEFP, Valeurs d'immissions mesurées en 1997. Doc. Env. 97, 1998 ; p 271.

9. Berge, E.; Beck, J.; Larssen, S.; Moussiopoulos, N.; Pulles, T. Air pollution in Europe 1997, European Environmental Agency, 1998 ; p 107.

10. Keating, M. Sommet de la Terre 1992. Un programme d'action. Centre pour notre avenir, Ed. Genève, 1993 ; p 70. 